\title{
Estimating gypsum Requirement under no-till based on machine learning technique ${ }^{1}$
}

\author{
Estimativa da necessidade de gesso em plantio direto baseada em técnica de \\ aprendizado de máquina
}

\author{
Alaine Margarete Guimarães ${ }^{2}$, Eduardo Fávero Caires ${ }^{3 *}$, Karine Sato da Silva ${ }^{4}$ e José Carlos Ferreira da Rocha²
}

\begin{abstract}
Chemical stratification occurs under no-till systems, including $\mathrm{pH}$, considering that higher levels are formed from the soil surface towards the deeper layers. The subsoil acidity is a limiting factor of the yield. Gypsum has been suggested when subsoil acidity limits the crops root growth, i.e., when the calcium (Ca) level is low and/or the aluminum (Al) level is toxic in the subsoil layers. However, there are doubts about the more efficient methods to estimate the gypsum requirement. This study was carried out to develop numerical models to estimate the gypsum requirement in soils under no-till system by the use of Machine Learning techniques. Computational analyses of the dataset were made applying the M5'Rules algorithm, based on regression models. The dataset comprised of soil chemical properties collected from experiments under no-till that received gypsum rates on the soil surface, throughout eight years after the application, in Southern Brazil. The results showed that the numerical models generated by rule induction M5'Rules algorithm were positively useful contributing for estimate the gypsum requirements under no-till. The models showed that Ca saturation in the effective cation exchange capacity (ECEC) was a more important attribute than Al saturation to estimate gypsum requirement in no-till soils.
\end{abstract}

Key words: Rule induction. Calcium. Aluminum. Subsoil acidity. Phosphogypsum.

\begin{abstract}
RESUMO - No sistema plantio direto ocorre estratificação química no perfil do solo, incluindo o pH, sendo que níveis mais altos são formados a partir da superfície do solo em direção às camadas mais profundas. A acidez do subsolo é um importante fator limitante da produção agrícola. O uso de gesso tem sido indicado quando a acidez do subsolo apresenta limitação para o crescimento radicular, ou seja, quando o teor de cálcio (Ca) é baixo e/ou o nível de alumínio (Al) é tóxico em camadas do subsolo. Entretanto, existem muitas dúvidas sobre os métodos mais apropriados para estimar a necessidade de gesso. Esse estudo foi realizado com o objetivo de desenvolver modelos numéricos, por meio de técnicas de aprendizado de máquina, para a estimativa da necessidade de gesso em solos sob plantio direto. Análises computacionais foram realizadas em um conjunto de dados, aplicando-se o algoritmo M5'Rules, baseado em modelos de regressão. Esses dados corresponderam aos atributos químicos de solos coletados de experimentos sob plantio direto que receberam doses de gesso na superfície, ao longo de até oito anos após a aplicação, na região Sul do Brasil. Os resultados mostraram que os modelos numéricos gerados pelo algoritmo M5'Rules foram de grande utilidade para estimar as doses de gesso a serem empregadas em plantio direto. Os modelos mostraram que a saturação por Ca na capacidade de troca de cations efetiva (CTCe) foi um atributo mais importante do que a saturação por Al para estimar a necessidade de gesso em solos sob plantio direto.
\end{abstract}

Palavras-chave: Indução de regras. Cálcio. Alumínio. Acidez do subsolo. Fosfogesso.

\footnotetext{
DOI: $10.5935 / 1806-6690.20150004$

*Autor para correspondência

${ }^{1}$ Recebido para publicação em 02/12/2013; aprovado em 29/12/2014

Pesquisa financiada pelo CNPq

${ }^{2}$ Departamento de Informática, Área de Inteligência Computacional, Universidade Estadual de Ponta Grossa, Av. General Carlos Cavalcanti 4748, Campus Uvaranas, Ponta Grossa-PR, Brasil, 84.030-900, alainemg@hotmail.com, jrocha@uepg.br

${ }^{3}$ Departamento de Ciência do Solo e Engenharia Agricola, Universidade Estadual de Ponta Grossa, Ponta Grossa-PR, Brasil, Bolsista de Produtividade em Pesquisa do CNPq, efcaires@hotmail.com

${ }^{4}$ Programa de Pós-Graduação em Computação Aplicada, Universidade Estadual de Ponta Grossa, Ponta Grossa-PR, Brasil, 84.030-900, karine.sato. silva@gmail.com
} 


\section{INTRODUCTION}

No-till (NT) systems with diversified crop rotations have stood out as one of the most effective strategies to improve the sustainability of agriculture in tropical and subtropical regions (HOBBS; SAYRE; GUPTA, 2008). Long-term NT systems are known to cause chemical stratification, including $\mathrm{pH}$, where high $\mathrm{pH}$ levels are formed in the upper few inches of the soil profile. Subsoil acidity is an important yield-limiting factor (CAIRES et al., 2008; DALLA NORA; AMADO, 2013; TANG et al., 2003).

Gypsum, a by-product of the phosphoric acid industry, mainly contains calcium sulfate and small amounts of $\mathrm{P}$ and $\mathrm{F}$ and is largely available in many parts of the world. In Brazil, approximately $4.8 \mathrm{Tg}$ are produced each year (RAIJ, 2008). When applied to the soil surface, gypsum moves down the profile during drainage, resulting in increases in the Ca supply and a reduction in toxic levels of $\mathrm{Al}$. As a result, better root growth, increased uptake of water and nutrients by plants roots and higher crop yields have been observed (BLUM; CAIRES; ALLEONI, 2013; DALLA NORA; AMADO, 2013; SORATTO; CRUSCIOL, 2008).

Gypsum application in Brazilian soils has been recommended when exchangeable Ca content is lower than $4 \mathrm{mmol} \mathrm{dm}^{-3}$ (RAIJ et al., 1996; RIBEIRO; GUIMARÃES; ALVAREZ, 1999) or $5 \mathrm{mmol}_{\mathrm{c}} \mathrm{dm}^{-3}$ (SOUSA; LOBATO, 2002), exchangeable $\mathrm{Al}$ content is higher than $5 \mathrm{mmol} \mathrm{dm}^{-3}$ (RIBEIRO; GUIMARÃES; ALVAREZ, 1999), and/or Al saturation is higher than 20\% (SOUSA; LOBATO, 2002), 30\% (RIBEIRO; GUIMARÃES; ALVAREZ, 1999), or 40\% (RAIJ et al., 1996) in subsurface layers (20-40 or 30-50 cm). Although reasonable, these $\mathrm{Ca}$ and $\mathrm{Al}$ levels considered critical to the root growth were based on few studies, and little is known about the benefits of using gypsum in NT soils that have no such limitations in deep layers. In a recent study (CAIRES et al., 2011a), the use of gypsum showed economic viability to maximize crop grain production in a long-term NT soil with a sufficient level of exchangeable $\mathrm{Ca}\left(\geq 8 \mathrm{mmol}_{\mathrm{c}} \mathrm{dm}^{-3}\right)$ and low levels of exchangeable $\mathrm{Al}\left(\leq 4 \mathrm{mmol}_{\mathrm{c}} \mathrm{dm}^{-3}\right)$ and $\mathrm{Al}$ saturation $(\leq 15 \%)$ in the subsoil layers $(20-60 \mathrm{~cm})$.

A consequence of gypsum application to soils is the displacement of other cation on the exchange complex. Consequently, exchangeable $\mathrm{Mg}$ and $\mathrm{K}$ leaching have often been observed in the studies with gypsum application (CAIRES et al., 2011a,b). The leaching of Mg after gypsum application can be beneficial for $\mathrm{Ca}$ and $\mathrm{K}$ plant nutrition and crop yield, when the soil has elevated Mg levels and a low $\mathrm{Ca} / \mathrm{Mg}$ ratio in the most superficial layers (CAIRES; FELDHAUS; BLUM, 2001; CAIRES et al., 2004).

Considering the doubts still exist about the most appropriate methods for estimating the gypsum requirement (GR) (RAIJ, 2008), it is possible that such estimate can be made by techniques of Machine Learning (ML), that are able to learn about facts and data, and handle new situations using reasoning and generalization.

ML can be used for pattern recognition with different purposes, including for predicting continuous numeric values. Considering the positive results obtained from the use of ML techniques in agronomy (GUIMARÃES; CATANEO; ZAZUETA, 2007; MEIRA; ROGRIGUES; MORAES, 2008), we hypothesize that is possible to develop numerical models to estimate GR in NT soils by the use of the M5'Rules algorithm (HOLMES; HALL; FRANK, 1999), which is based on the ML concepts.

\section{MATERIAL AND METHODS}

\section{Sites Description}

The study was performed in three field sites located in the Center-South region of Parana State, Brazil. The first site, here named site A, is located in Ponta Grossa $\left(25^{\circ} 8^{\prime} \mathrm{S}, 50^{\circ} 15^{\prime} \mathrm{W}\right.$, and average altitude of $\left.853 \mathrm{~m}\right)$, on a loamy Typic Hapludox (295 $\mathrm{g} \mathrm{kg}^{-1}$ of clay) with high acidity. Prior to the establishment of the experiment, the field site had been used under NT cultivation during 15 years. Table 1 shows results of soil chemical analyses for different depths before the establishment of the experiment. Gypsum at the rates of $0,4,8$, and $12 \mathrm{tha}^{-1}$ were broadcast on the soil surface in 1993 and a randomized complete block design was used, with three replications. Plot size was $50.4 \mathrm{~m}^{2}(8.0 \times 6.3 \mathrm{~m})$. Samples of soil were taken at 0-10, 10-20, 20-40, and 40-60 cm depths at 8, 20, 32, 44, and 56 months after gypsum application.

The second site, named site $\mathrm{B}$, also is located in Ponta Grossa $\left(25^{\circ} 10^{\prime} \mathrm{S}, 50^{\circ} 05^{\prime} \mathrm{W}\right.$, and average altitude of $970 \mathrm{~m})$, on a clayey Rhodic Hapludox $\left(580 \mathrm{~g} \mathrm{~kg}^{-1}\right.$ of clay) with medium acidity, previously used for pasture. Table 2 shows results of soil chemical analyses for different depths before the establishment of the experiment. Gypsum at the rates of $0,3,6$, and $9 \mathrm{tha}^{-1}$ were broadcast on the soil surface in 1998 and a randomized complete block design was used, with three replications. Plot size was $56.0 \mathrm{~m}^{2}$ $(8.0 \times 7.0 \mathrm{~m})$. Samples of soil were taken at 0-10, 10-20, 20-40, and 40-60 cm depths at 8, 20, 32, 44, 56, 68, 80, and 92 months after gypsum application.

The third site, named site $\mathrm{C}$, is located in Guarapuava $\left(25^{\circ} 17^{\prime} \mathrm{S}, 51^{\circ} 48^{\prime} \mathrm{W}\right.$, and average altitude of $\left.1080 \mathrm{~m}\right)$, on a clayey Typic Hapludox (650 $\mathrm{g} \mathrm{kg}^{-1}$ of clay) with low acidity. Prior to the establishment of the experiment, the field site had been used under NT cultivation during 15 years. Table 3 shows results of soil chemical analyses for different depths before the establishment of the experiment. Gypsum at the rates of $0,4,8$, and $12 \mathrm{tha}^{-1}$ were broadcast 
on the soil surface in 2005 and a randomized complete block design was used, with four replications. Plot size was $49.0 \mathrm{~m}^{2}(7.0 \times 7.0 \mathrm{~m})$. Samples of soil were taken at $0-10,10-20,20-40$, and $40-60 \mathrm{~cm}$ depths, at 8, 20 and 32 months after gypsum application.
According to Köppen-Geiger System (PEEL; FINLAYSON; MCMAHON, 2007), the climate of the three field sites is $\mathrm{Cfb}$, with mild summer and frequent frosts during the winter. The average annual air temperature is of $17^{\circ} \mathrm{C}$, and the average air temperature of the coldest month is $13{ }^{\circ} \mathrm{C}$ and

Table 1 - Results of soil chemical analyses for different depths before the establishment of the experiment at site A

\begin{tabular}{|c|c|c|c|}
\hline \multirow{2}{*}{ Properties } & \multicolumn{3}{|c|}{ Depth $(\mathrm{cm})$} \\
\hline & $0-20$ & $20-40$ & $40-60$ \\
\hline $\mathrm{pH}$ (1:2.5 soil: $0.01 \mathrm{~m} \mathrm{CaCl}_{2}$ suspension) & 4.5 & 4.4 & 4.4 \\
\hline Total acidity $\mathrm{pH} 7.0(\mathrm{H}+\mathrm{Al})\left(\mathrm{mmol}_{\mathrm{c}} \mathrm{dm}^{-3}\right)$ & 58 & 58 & 50 \\
\hline Organic carbon $\left(\mathrm{g} \mathrm{dm}^{-3}\right)$ & 19 & 18 & 16 \\
\hline $\mathrm{P}\left(\right.$ Mehlich-1) $\left(\mathrm{mg} \mathrm{dm}^{-3}\right)$ & 9.0 & 4.0 & 2.0 \\
\hline \multicolumn{4}{|c|}{ Exchangeable cations $\left(\mathrm{mmol}_{(+)} \mathrm{dm}^{-3}\right)$} \\
\hline $\mathrm{Ca}$ & 16 & 16 & 16 \\
\hline $\mathrm{Mg}$ & 10 & 10 & 9 \\
\hline K & 1.4 & 1.5 & 1.5 \\
\hline $\mathrm{Al}$ & 6 & 6 & 6 \\
\hline Effective cation exchange capacity (ECEC) (mmolc $\left.\mathrm{dm}^{-3}\right)$ & 33.4 & 33.5 & 32.5 \\
\hline Cation exchange capacity pH $7.0(\mathrm{CEC})\left(\mathrm{mmolc}_{\mathrm{dm}}^{-3}\right)$ & 85.4 & 85.5 & 76.5 \\
\hline Base saturation $(\%) \dagger$ & 32 & 32 & 35 \\
\hline Al saturation $(\%) \ddagger$ & 18 & 18 & 18 \\
\hline
\end{tabular}

${ }^{\dagger}$ Base saturation $=100(\mathrm{Ca}+\mathrm{Mg}+\mathrm{K} / \mathrm{CEC} \mathrm{pH} 7.0) .{ }^{\ddagger} \mathrm{Al}$ saturation $=100(\mathrm{Al} / \mathrm{ECEC})$

Table 2 - Results of soil chemical analyses for different depths before the establishment of the experiment at site B

\begin{tabular}{lrrr}
\hline \multicolumn{1}{c}{ Properties } & \multicolumn{3}{c}{ Depth $(\mathrm{cm})$} \\
\cline { 2 - 4 } & $0-20$ & $20-40$ & $40-60$ \\
\hline $\mathrm{pH}\left(1: 2.5\right.$ soil:0.01 $\mathrm{m} \mathrm{CaCl}_{2}$ suspension $)$ & 4.7 & 4.2 & 4.2 \\
Total acidity $\mathrm{pH} 7.0(\mathrm{H}+\mathrm{Al})\left(\mathrm{mmolc} \mathrm{dm}^{-3}\right)$ & 78 & 97 & 84 \\
Organic carbon $\left(\mathrm{g} \mathrm{dm}^{-3}\right)$ & 31 & 21 & 14 \\
$\mathrm{P}\left(\right.$ Mehlich-1) $\left(\mathrm{mg} \mathrm{dm}^{-3}\right)$ & 0.3 & 0.1 & 0.1 \\
\hline Exchangeable cations $\left(\mathrm{mmol}_{\mathrm{c}} \mathrm{dm}^{-3}\right)$ & & 7 & 6 \\
\hline $\mathrm{Ca}$ & 25 & 8 & 1.5 \\
$\mathrm{Mg}$ & 20 & 2.2 & 8 \\
$\mathrm{~K}$ & 3.6 & 8 & 22.5 \\
$\mathrm{Al}$ & 3 & 25.2 & 98.5 \\
Effective cation exchange capacity $(\mathrm{ECEC})\left(\mathrm{mmol}_{\mathrm{c}} \mathrm{dm}^{-3}\right)$ & 51.6 & 114.2 & 15 \\
Cation exchange capacity pH $7.0(\mathrm{CEC})\left(\mathrm{mmol}_{\mathrm{c}} \mathrm{dm}^{-3}\right)$ & 126.6 & 15 & 36 \\
Base saturation $(\%) \dagger$ & 38 & 32 & \\
Al saturation $(\%) \ddagger$ & 6 & & \\
\hline
\end{tabular}

${ }^{\dagger}$ Base saturation $=100(\mathrm{Ca}+\mathrm{Mg}+\mathrm{K} / \mathrm{CEC} \mathrm{pH} 7.0) .{ }^{\ddagger} \mathrm{Al}$ saturation $=100(\mathrm{Al} / \mathrm{ECEC})$ 
Table 3 - Results of soil chemical analyses for different depths before the establishment of the experiment at site C

\begin{tabular}{|c|c|c|c|}
\hline \multirow{2}{*}{ Properties } & \multicolumn{3}{|c|}{ Depth $(\mathrm{cm})$} \\
\hline & $0-20$ & $20-40$ & $40-60$ \\
\hline $\mathrm{pH}\left(1: 2.5\right.$ soil: $0.01 \mathrm{~m} \mathrm{CaCl}_{2}$ suspension $)$ & 5.9 & 5.2 & 5.0 \\
\hline Total acidity pH $7.0(\mathrm{H}+\mathrm{Al})\left(\mathrm{mmol}_{\mathrm{c}} \mathrm{dm}^{-3}\right)$ & 45 & 62 & 67 \\
\hline Organic carbon $\left(\mathrm{g} \mathrm{dm}^{-3}\right)$ & 28 & 20 & 17 \\
\hline P (Mehlich-1) (mg dm $\left.{ }^{-3}\right)$ & 4.7 & 1.8 & 1.5 \\
\hline \multicolumn{4}{|c|}{ Exchangeable cations $\left(\mathrm{mmol}_{\mathrm{c}} \mathrm{dm}^{-3}\right)$} \\
\hline $\mathrm{Ca}$ & 48 & 23 & 15 \\
\hline $\mathrm{Mg}$ & 22 & 29 & 10 \\
\hline $\mathrm{K}$ & 4.2 & 2.4 & 4.2 \\
\hline $\mathrm{Al}$ & 0 & 0 & 0 \\
\hline Effective cation exchange capacity $(\mathrm{ECEC})\left(\mathrm{mmol}_{\mathrm{c}} \mathrm{dm}^{-3}\right)$ & 74.2 & 54.4 & 29.2 \\
\hline Cation exchange capacity pH 7.0 (CEC) $\left(\mathrm{mmol}_{\mathrm{c}} \mathrm{dm}^{-3}\right)$ & 119.2 & 116.4 & 96.2 \\
\hline Base saturation $(\%) \dagger$ & 62 & 47 & 30 \\
\hline $\mathrm{Al}$ saturation $(\%) \ddagger$ & 0 & 0 & 0 \\
\hline
\end{tabular}

${ }^{\dagger}$ Base saturation $=100(\mathrm{Ca}+\mathrm{Mg}+\mathrm{K} / \mathrm{CEC} \mathrm{pH} 7.0) .{ }^{*} \mathrm{Al}$ saturation $=100(\mathrm{Al} / \mathrm{ECEC})$

of the hottest month is not higher than $22{ }^{\circ} \mathrm{C}$. The average annual rainfall is $1600 \mathrm{~mm}$, with rainfall concentrated between the September to April months.

The three field sites were cultivated under NT with crop rotation. Maize (Zea mays L.) or soybean (Glycine max L. Merril) were sown during the spring-summer seasons, and black oat (Avena strigosa Schreb.) or wheat (Triticum aestivum L.) or barley (Hordeum vulgare L.) in autumn-winter season. According to the crops requirements and nutrients levels in the soil fertilizers were applied, as recommended for the Paraná State. More details about the experimental sites and the effects of gypsum application on crop grain yields are reported in Caires et al. (1999); Caires; Feldhaus; Blum, (2001); Caires et al. (2002, 2004, 2011b).

For the soil samples taken in the three experimental sites, the exchangeable $\mathrm{Al}, \mathrm{Ca}, \mathrm{Mg}$ and $\mathrm{K}$ contents were determined according to the standard methods adopted by the Agronomic Institute of Parana (PAVAN et al., 1992). The effective cation exchange capacity (ECEC) was calculated by summing the exchangeable cations $(\mathrm{Al}+\mathrm{Ca}+\mathrm{Mg}+\mathrm{K})$ and the $\mathrm{Al}, \mathrm{Ca}, \mathrm{Mg}$ and $\mathrm{K}$ saturation in $\mathrm{ECEC}$ was calculated according to the equations: Al saturation $(\%)[m=100$ (Al/ECEC)], Ca saturation (\%) $[\mathrm{CaSat}=100(\mathrm{Ca} /$ ECEC)], Mg saturation (\%) [MgSat $=100(\mathrm{Mg} / \mathrm{ECEC})]$, and $\mathrm{K}$ saturation $(\%)[\mathrm{KSat}=100(\mathrm{~K} / \mathrm{ECEC})]$.

The number of observations of $\mathrm{Al}, \mathrm{Ca}, \mathrm{Mg}$, and $\mathrm{K}$ contents and saturation at the different soil depths throughout the period of the experiments were 240, 384, and 192 , respectively at A, B, and C sites.

\section{Data Analysis Method}

The data analysis was made using ML techniques, and the M5'Rules algorithm implemented in the software Weka (WITTEN; FRANK; HALL, 2011) was adopted. This model tree induction algorithm for predicting numeric values presents a better performance when compared to others (DUGGAL; SINGH, 2012) and is based on regression models. Therefore, each leaf node of the tree structure has a regression model called rule. In this study, each regression model (rule) estimated the GR considering the $\mathrm{Al}, \mathrm{Ca}, \mathrm{Mg}$ and $\mathrm{K}$ saturation. The selection of the best rules of GR estimative, in $\mathrm{t} \mathrm{ha}^{-1}$, was established considering the correlation coefficient, relative absolute error, root relative squared error and total of instances covered by the rule, that represent the confidence level of the rule. In this way, the use of M5'Rules algorithm is considered an effective alternative to data analysis as soon as it uses strong statistics concepts and well known ML techniques.

\section{RESULTS AND DISCUSSION}

\section{Site A}

The analysis of all instances in the five sampling time (8, 20, 32, 44, and 56 months after gypsum application), during the period from 1994 to 1998, did not generate efficient rules. When only the Ca saturation ( $\mathrm{CaSat}$ ) was considered in all soil profiles $(0-60 \mathrm{~cm})$ during the same evaluation period, it was 
Table 4 - Rules generated to estimate gypsum rate based on site A dataset

\begin{tabular}{|c|c|c|}
\hline Rule Number & Rule generated to estimate gypsum rate (GR) & $\mathrm{r}$ \\
\hline $\mathrm{R} 1$ & $\mathrm{GR}=0.0679 \times$ time $^{2} 0.1485 \times \mathrm{CaSat}_{20-40}+0.1406 \times \mathrm{CaSat}_{40-60}-10.2964$ & 0.55 \\
\hline $\mathrm{R} 2$ & $\mathrm{GR}=-0.0605 \times$ time $-0.3843 \times \mathrm{m}_{20-40}$ & 0.46 \\
\hline R3 & $\mathrm{GR}=-0.3735 \times \mathrm{m}_{40-60}+11.961$ & 0.36 \\
\hline R4 & IF CaSat $_{10-20}>38.4$ THEN GR $=0.0439 \times$ time $+0.0923 \times \mathrm{CaSat}_{0-10}+0.3605 \times \mathrm{m}_{0-10}-0.2731 \times \mathrm{m}_{20-40}+0.7826$ & 0.43 \\
\hline R5 & $\mathrm{GR}=0.0638 \times$ time $-0.2176 \times \mathrm{MgSat}_{0-10}-0.169 \times \mathrm{MgSat}_{10-20}+13.5279$ & 0.42 \\
\hline R6 & $\mathrm{GR}=0.0657 \times$ time $-1.7082 \times \mathrm{KSat}_{0-10}+1.999 \times \mathrm{KSat}_{10-20}-1.5917 \times \mathrm{KSat}_{20-40}+10.1414$ & 0.30 \\
\hline R7 & $\mathrm{GR}=0.1447 \times \mathrm{CaSat}_{20-40}+0.1547 \times \mathrm{CaSat}_{40-60}-9.6337$ & 0.57 \\
\hline R8 & $\mathrm{GR}=-0.4525 \times \mathrm{m}_{40-60}+12.4407$ & 0.59 \\
\hline R9 & $\mathrm{GR}=-0.2113 \times \mathrm{MgSat}_{0-10}-0.1817 \times \mathrm{MgSat}_{10-20}+14.9369$ & 0.38 \\
\hline $\mathrm{R} 10$ & $\mathrm{GR}=-2.4496 \times \mathrm{KSat}_{20-40}+11.3565$ & 0.26 \\
\hline
\end{tabular}

observed that the GR estimative was affected by the sampling time and the Ca saturation $(\mathrm{r}=0.55)$ at $20-40$ and $40-60 \mathrm{~cm}$ depths (Table 4, R1). GR estimative was not better when the Al saturation $(m)$ was considered at $20-40 \mathrm{~cm}(\mathrm{r}=0.46)$ (Table 4, R2) and 40-60 cm ( $\mathrm{r}=0.36)$ (Table 4, R3) depths, and the same occurred when the CaSat and the $m$ in all of the studied depths were considered $(r=0.43)$ (Table 4, R4). Even with the time interference after gypsum addition to estimate GR, these results showed that the $\mathrm{Ca}$ saturation in the subsoil (20-40 and 40-60 cm) was a more adequate attribute to estimate $\mathrm{GR}$ than $\mathrm{Al}$ saturation, alone or in combination with the Ca saturation.

With increasing gypsum rates leaching of $\mathrm{Mg}$ and $\mathrm{K}$ exchangeable in the soil can occur (CAIRES et al., 2011a,b). So, it would be expected a negative correlation between GR and $\mathrm{MgSat}$ and $\mathrm{KSat}$ values, mainly in the soil surface layers. In fact, the analysis performed during the period from 2004 to 2008 revealed that $M g S a t$ at $0-10$ and $10-20 \mathrm{~cm}$ depths was negatively correlated $(r=0.42)$ with GR (Table 4, R5). For KSat the correlation obtained was much lower $(\mathrm{r}=0.30)$ (Table 4, R6), showing greater influence of the gypsum addition in leaching of exchangeable $\mathrm{Mg}$ than exchangeable $\mathrm{K}$, which is in agreement with the results obtained in other studies with gypsum (CAIRES et al., 2011a,b; ZAMBROSI; ALLEONI; CAIRES, 2007).

Because the sampling time affects the estimated results due to the long-term evaluation, the instances analysis was performed only for instances of the first three sampling time (8, 20, and 32 months), in all soil profiles $(0-60 \mathrm{~cm})$. For the CaSat, a rule generated for estimating GR (Table 4, R7) presented a little better correlation $(\mathrm{r}=0.57)$ related to all the evaluation period. For the Al saturation values, it was observed that the rule generated for estimating GR showed a better correlation $(\mathrm{r}=0.59)$ having proved influence of the $m$ values at $40-60 \mathrm{~cm}$ depth (Table $4, \mathrm{R} 8$ ). The correlations to the rules generated as a function of
MgSat (r = 0.38) (Table 4, R9) and KSat (r = 0.26) (Table 4, R10) were not better than those observed throughout the evaluation period.

The higher maize grain yield in this soil was obtained after gypsum application at $9.5 \mathrm{t} \mathrm{ha}^{-1}$ (CAIRES et al., 1999), in the second evaluation time (20 months). Considering the best rules generated, the GR of $9.5 \mathrm{t} \mathrm{ha}^{-1}$ it would be obtained for Ca saturation in the ECEC of $64 \%$ at 20-40 and 40-60 cm depths (Table 4, R1 and R7) and for Al saturation of $6.5 \%$ at the $40-60 \mathrm{~cm}$ depth (Table 4, R8). Thus, the maximum maize grain yield should have been achieved for Ca saturation of $64 \%$ or $\mathrm{Al}$ saturation of $6.5 \%$ in the subsoil. It is noteworthy that the use of gypsum showed economic viability to maximize crop grain yield in a NT soil presenting low levels of Al saturation $(\leq$ $15 \%)$ in the subsurface layers $(20-60 \mathrm{~cm}$ ) (CAIRES et al., 2011a), in agreement with the results obtained in this study. Since the generated rules admit other possibilities of Ca saturation at 20-40 and 40-60 cm layers for obtaining GR resulting in the maximum maize yield $\left(9.5 \mathrm{tha}^{-1}\right)$, they could serve as alternatives to estimate GR.

\section{Site B}

The analysis of all instances in the eight sampling time $(8,20,32,44,56,68,80$, and 92 months after gypsum application), during the period from 1999 to 2006 did not generate efficient rules, similar to that happened in the site A. Becoming alone the Ca saturation ( $\mathrm{CaSat}$ ) and considering all the soil profiles $(0-60 \mathrm{~cm})$, during the same evaluation period, it was found that GR was influenced by the sampling time and the $\mathrm{Ca}$ saturation $(\mathrm{r}=0.58)$ at $0-10$ and $40-60 \mathrm{~cm}$ depths (Table 5, R11).

Estimating GR taking in account the Al saturation $(m)$ in the soil profiles was worst, but the correlation to the generated rule was a little more close $(r=0.60)$ when considering the CaSat and $m$ at the studied depths 
Table 5 - Rules generated to estimate gypsum rate based on site B dataset

\begin{tabular}{|c|c|c|}
\hline Rule Number & Rule generated to estimate gypsum rate (GR) & $\mathrm{r}$ \\
\hline R11 & $\mathrm{GR}=0.0211 \times$ time $^{2} 0.1917 \times \mathrm{CaSat}_{0-10}+0.0545 \times \mathrm{CaSat}_{40-60}-10.7622$ & 0.58 \\
\hline R12 & $\mathrm{GR}=0.1881 \times \mathrm{m}_{10-20}-0.0776 \times \mathrm{m}_{40-60}+0.2422 \times \mathrm{CaSat}_{0-10}+0.0652 \times \mathrm{CaSat}_{10-20}-0.0508 \times \mathrm{CaSat}_{20-40}-12.8042$ & 0.60 \\
\hline R13 & $\mathrm{GR}=-0.2709 \times \mathrm{MgSat}_{0-10}+11.4538$ & 0.60 \\
\hline R14 & $\mathrm{GR}=0.63 \times \mathrm{KSat}_{10-20}+8.5353$ & 0.30 \\
\hline R15 & $\mathrm{IF} \mathrm{m}_{20-40} \leq 13.87 \mathrm{THEN} \mathrm{GR}=0.3011 \times \mathrm{m}_{0-10}-0.2853 \times \mathrm{m}_{20-40}+8.1864$ & 0.35 \\
\hline R16 & IF CaSat $_{0-10} \leq 65.5$ THEN GR $^{2} 0.0272 \times$ time $^{2}+0.113 \times \mathrm{CaSat}_{0-10}+0.1187 \times \mathrm{CaSat}_{10-20}-0.0306 \times \mathrm{CaSat}_{40-60}-9.6271$ & 0.78 \\
\hline R17 & $\begin{array}{c}\text { IF CaSat }_{0-10} \leq \text { 65.5 AND CaSat } \\
\text { CaSa-20 }_{0-10} \leq 50.6 \text { THEN GR }=0.1101 \times \mathrm{CaSat}_{10-20}-0.0475 \times \mathrm{CaSat}_{20-40}-11.1357\end{array}$ & 0.74 \\
\hline R18 & $\mathrm{GR}=-0.2935 \times \mathrm{MgSat}_{0-10}-0.1156 \times \mathrm{MgSat}_{10-20}+0.1366 \times \mathrm{MgSat}_{40-60}+10.2784$ & 0.82 \\
\hline R19 & $\mathrm{GR}=-1.1172 \times \mathrm{KSat}_{10-20}+12.5751$ & 0.53 \\
\hline
\end{tabular}

(Table 5, R12). These results suggest the Ca saturation in the ECEC in both topsoil $(0-10 \mathrm{~cm})$ and subsoil $(40-60 \mathrm{~cm})$ affects the GR estimative and the combination of CaSat with $m$ causes little amelioration in the correlation.

Because the gypsum application can cause leaching of exchangeable cations in the soil (CAIRES et al., 2011a,b), it was observed a negative correlation $(\mathrm{r}=0.60)$ between the $\mathrm{GR}$ and the MgSat at 0-10 cm depth (Table 5, R13), considering all the evaluated period (1999 to 2006). According to it was observed also to the site A, the correlation obtained to the KSat was low $(r=0.30)$ (Table 5, R14), showing the less influence of the gypsum addition in the leaching of $\mathrm{K}$ exchangeable than $\mathrm{Mg}$ exchangeable in the soil (CAIRES et al., 2011a,b; ZAMBROSI; ALLEONI; CAIRES, 2007).

When the analysis of the instances was performed only for the three first sampling time (8, 20, and 32 months), in all soil profiles $(0-60 \mathrm{~cm})$, the generated rule for estimating the GR by the $\mathrm{Al}$ saturation $(m)$ continued to have low correlation $(\mathrm{r}=0.35)$ (Table 5, R15) and could be applied only when $m_{20-40}$ was $\leq 13.87 \%$, but it was observed an improvement of the correlations obtained with the CaSat and by combining of $\mathrm{CaSat}$ and $\mathrm{m}$. For the CaSat, the generated rule for estimating GR (Table 5, R16) presented a higher correlation coefficient $(\mathrm{r}=0.78)$, but proved to be valid only for $\mathrm{CaSat} \leq 65.5 \%$ at the $0-10 \mathrm{~cm}$ depth. The combined analysis of the CaSat and $m$ data for estimating GR also indicated high correlation $(\mathrm{r}=0.74)$ and smallest error, but for a specific condition of CaSat $\leq 65.5 \%$ at the $0-10 \mathrm{~cm}$ depth and CaSat $\leq 50.6 \%$ at the 10-20 cm depth (Table 5, R17). Despite the increase in correlation coefficients and decrease in error, the specificity of the conditions generated for the application of such rules imposes serious constraints for the GR estimation.

The GR estimated based on the MgSat (Table 5, R18) had high correlation ( $r=0.82)$, showing that, in that evaluation period $(8,20$, and 32 months), increasing the gypsum rates resulted in lower values of $\mathrm{MgSat}$ at the 0-10 and 10-20 cm depths, and higher at the 40-60 cm depth.
Related to the KSat, the correlation coefficient of the rule (Table 5, R19) was slightly higher $(\mathrm{r}=0.53)$, but even lower than that observed to the MgSat.

The higher grain yields of barley (CAIRES; FELDHAUS; BLUM, 2001), wheat (CAIRES et al., 2002), and maize (CAIRES et al., 2004) in this soil was obtained after gypsum application at 9.0, 8.2, and 9.0 $\mathrm{tha}^{-1}$, respectively, in the first, second and third evaluation time. Considering the generated rule for CaSat during all the evaluation period, which has no a specific condition for its application (Table 5, R11), it is observed the GR from 8.2 to $9.0 \mathrm{t} \mathrm{ha}^{-1}$ in this period would be obtained for Ca saturation in the ECEC of about $85 \%$ at the $0-10 \mathrm{~cm}$ depth and about $64 \%$ at the $40-60$ cm depth.

Whereas the inclusion of $\mathrm{Al}$ saturation has not resulted in a closest correlation, these results suggest that the values of Ca saturation in the ECEC of the surface $(0-10 \mathrm{~cm})$ and subsurface $(40-60 \mathrm{~cm})$ layers could be good indicators of the estimate GR. Since the generated rules admit to other possibilities for obtaining GR resulting in the higher crop grain yields (8.2 to $9.0 \mathrm{t} \mathrm{ha}^{-1}$ ), they could serve as alternatives to assist in defining the GR.

\section{Site C}

The analysis of all instances in the three sampling time $(8,20$, and 32 months after gypsum application), during the period from 2006 to 2008, showed the GR estimative was affected by the CaSat at 0-10 and 10-20 cm depths, and KSat at the $0-10 \mathrm{~cm}$ depth $(\mathrm{r}=0.76)$ (Table $6, \mathrm{R} 20)$. The generated rule shows that increasing the GR would result in higher values CaSat at 0-10 and 10-20 cm depths, and in lower value of KSat at the $0-10 \mathrm{~cm}$ depth. When the CaSat effect was isolated, considering all the soil profiles $(0-60 \mathrm{~cm})$, during the same evaluation period, it was observed the CaSat at 010 and $10-20 \mathrm{~cm}$ depths affected the GR estimative $(\mathrm{r}=$ 0.74) (Table 6, R21). Because at this site was not detected the presence of exchangeable $\mathrm{Al}$ in the surface and subsurface 
Table 6 - Rules generated to estimate gypsum rate based on site $\mathrm{C}$ dataset

\begin{tabular}{lrc}
\hline Rule Number & Rule generated to estimate gypsum rate $(\mathrm{GR})$ & $\mathrm{r}$ \\
\hline R20 & $\mathrm{GR}=0.2645 \times \mathrm{CaSat}_{0-10}+0.1104 \times \mathrm{CaSat}_{10-20}-1.1456 \times \mathrm{KSat}_{0-10}-17.5001$ & 0.76 \\
R21 & $\mathrm{GR}=0.3108 \times \mathrm{CaSat}_{0-10}+0.1181 \times \mathrm{CaSat}_{10-20}-25.4056$ & 0.74 \\
R22 & $\mathrm{GR}=-0.0748 \times \mathrm{time}-0.2782 \times \mathrm{MgSat}_{0-10}-0.191 \times \mathrm{MgSat}_{10-20}+18.8598$ & 0.69 \\
R23 & IF KSat $_{20-40} \leq 4.15 \mathrm{THEN} \mathrm{GR}=-2.5294 \times \mathrm{KSat}_{0-10}-0.6626 \times \mathrm{KSat}_{20-40}+17.6311$ & 0.60 \\
\hline
\end{tabular}

layers, there was no change of the rule generated for the $\mathrm{Ca}$ saturation when $\mathrm{Al}$ saturation was included in the analysis.

The GR estimative was correlated $(r=0.69)$ with the sampling time and the $\mathrm{Mg}$ saturation at $0-10$ and 10-20 cm depths (Table 6, R22), during the period from 2006 to 2008. According to the rule, higher GR would correspond to lower $\mathrm{Mg}$ saturation values at $0-10$ and 10-20 cm depths. This effect results of leaching of exchangeable $\mathrm{Mg}$ that occurs in soil after gypsum addition (CAIRES et al., 2011a,b). The influence of the sampling time, in this case, shows the leaching of exchangeable $\mathrm{Mg}$ after gypsum application continued occurring during the evaluated period, further reducing the $\mathrm{Mg}$ saturation at 0-10 and 10-20 cm depths.

Related to the $\mathrm{K}$ saturation, the generated rule for the GR estimative (Table 6, R23) showed to be valid $(r=0.60)$ only for the case of the $K$ saturation $\leq 4.15 \%$ at the $20-40 \mathrm{~cm}$ depth. In any case, the rule indicates that higher GR correspond to smaller values of $\mathrm{K}$ saturation, particularly in the soil surface layer $(0-10 \mathrm{~cm})$, which would be related to the leaching of exchangeable $\mathrm{K}$ in the soil due to the application of gypsum (CAIRES et al., 2011b).

The higher maize grain yield in this soil was obtained after gypsum application at $7.8 \mathrm{t} \mathrm{ha}^{-1}$ (CAIRES et al., 2011b), in the first evaluation time. Considering the generated rule based on the Ca saturation during the period from 2006 to 2008 (Table 6, R21), it is noted the GR of $7.8 \mathrm{t} \mathrm{ha}^{-1}$ would be obtained for Ca saturation in the ECEC about $80 \%$ at the $0-10 \mathrm{~cm}$ depth, and $70 \%$ at the $10-20 \mathrm{~cm}$ depth. The rule admits to other possibilities of Ca saturation at $0-10$ and $10-20 \mathrm{~cm}$ depths to obtain the
GR that resulted in the higher maize grain yield $\left(7.8 \mathrm{t} \mathrm{ha}^{-1}\right)$, but it is clear the $\mathrm{Ca}$ saturation in the surface layers is an important component for GR estimative in soil that does not present problems related to Al toxicity in the profile. In other study performed under a NT it was verified the economic viability of using gypsum to maximize production of grain crops in a soil with $\mathrm{Ca}$ saturation in the ECEC values ranging from 59 to $67 \%$, at the $0-10 \mathrm{~cm}$ depth, and from 47 to $57 \%$, at the $10-20$ cm depth (CAIRES et al., 2011a), which agrees with the results obtained in this study.

\section{Sites A, B, and C}

The joint analysis of all instances in the three sites (A, B, and C), considering the first three times (8, 20, and 32 months after gypsum application) and the four sampling depths (0-10, 10-20, 20-40, and 40-60 cm), showed the generated rules based on the Ca saturation in the ECEC and the $\mathrm{Al}$ saturation $(m)$ were the ones that showed the closest correlation with the GR estimative (Table 7). Even considering all depths of the soil profile $(0-60 \mathrm{~cm})$, the rule generated for the GR estimative showed a strong correlation $(\mathrm{r}=0.70)$ with the Ca saturation only at the $0-10 \mathrm{~cm}$ depth (Table 7, R24).

The generated rule considering only $\mathrm{Al}$ saturation $(\mathrm{m})$ was related to the $m$ value at the $40-60 \mathrm{~cm}$ depth (Table 7, $\mathrm{R} 25)$, but the correlation was very weak $(r=0.26)$. When the possibility of combining the $\mathrm{Ca}$ saturation and $\mathrm{Al}$ saturation ( $m$ ) was considered, the generated rule presented strong correlation $(\mathrm{r}=0.78)$ with $m$ at the $0-10 \mathrm{~cm}$ depth and $\mathrm{Ca}$ saturation at 0-10 and 10-20 cm depths (Table 7, R26). Certainly because the higher soil acidity of the sites $\mathrm{A}$ and B compared to the site $C$ the rule presented relation with $m$ in the soil surface layer $(0-10 \mathrm{~cm})$. Because the problems

Table 7 - Rules generated to estimate gypsum rate based on sites A, B, and C dataset

\begin{tabular}{lcc}
\hline Rule Number & Rule generated to estimate gypsum rate $(\mathrm{GR})$ & $\mathrm{r}$ \\
\hline $\mathrm{R} 24$ & $\mathrm{GR}=0.2898 \times \mathrm{CaSat}_{0-10}-14.909$ & 0.70 \\
$\mathrm{R} 25$ & $\mathrm{GR}=-0.1411 \times \mathrm{m}_{40-60}+6.9306$ & 0.26 \\
$\mathrm{R} 26$ & $\mathrm{GR}=0.7007 \times \mathrm{m}_{0-10}+0.2733 \times \mathrm{CaSat}_{0-10}+0.1297 \times \mathrm{CaSat}_{10-20}-22.969$ & 0.78 \\
\hline
\end{tabular}


related to the presence of $\mathrm{Al}$ in the soil surface layer are easily corrected by applying lime, it is evident the importance of the Ca saturation in the soil surface layers to estimate GR when the soil acidity is corrected by liming.

For the three studied sites the higher grain yields of maize, wheat or barley occurred with GR ranging from 7.8 to $9.5 \mathrm{t} \mathrm{ha}^{-1}$ (CAIRES et al., 1999; CAIRES; FELDHAUS; BLUM, 2001; CAIRES et al., 2002, 2004, 2011b). Since the GR was strongly correlated with the Ca saturation in the ECEC at the 0-10 cm layer (Table 7, R24), it is possible that the higher crop grain yields under NT systems would be obtained with Ca saturation in the ECEC values in the soil surface layer $(0-10 \mathrm{~cm})$ ranging from 78 to $84 \%$.

\section{CONCLUSIONS}

1. The regression models generated by rule induction M5'Rules algorithm were positively useful contributing for determining gypsum requirement to be used in NT soils.

2. The models showed that Ca saturation in the ECEC was a more important attribute than $\mathrm{Al}$ saturation to estimate gypsum requirement in NT soils.

\section{REFERENCES}

BLUM, S. C.; CAIRES, E. F.; ALLEONI, L. R. F. Lime and phosphogypsum application and sulfate retention in subtropical soils under no-till system. Journal of Soil Science and Plant Nutrition, v. 13, n. 2, p. 279-300, 2013.

CAIRES, E. F. et al. Produção de milho, trigo e soja em função das alterações das características químicas do solo pela aplicação de calcário e gesso na superfície, em sistema de plantio direto. Revista Brasileira de Ciência do Solo, v. 23, n. 2, p. 315-327, 1999.

CAIRES, E. F.; FELDHAUS, I. C.; BLUM, J. Crescimento radicular e nutrição da cevada em função da calagem e aplicação de gesso. Bragantia, v. 60, n. 2, p. 213-223, 2001.

CAIRES, E. F. et al. Lime and gypsum application on the wheat crop. Scientia Agricola, v. 59, n. 2, p. 357-364, 2002.

CAIRES, E. F. et al. Alterações químicas do solo e resposta do milho à calagem e aplicação de gesso. Revista Brasileira de Ciência do Solo, v. 28, n. 1, p. 125-136, 2004.

CAIRES, E. F. et al. Effects of soil acidity amelioration by surface liming on no-till corn, soybean, and wheat root growth and yield. European Journal of Agronomy, v. 28, n. 1, p. 57-64, 2008.

CAIRES, E. F. et al. Use of gypsum for crop grain production under a subtropical no-till cropping system. Agronomy Journal, v. 103, n. 6, p. 1804-1814, 2011 a.

CAIRES, E. F. et al. Surface application of gypsum in low acidic Oxisol under no-till cropping system. Scientia Agricola, v. 68 , n. 2 , p. $209-216,2011$ b.
DALLA NORA, D.; AMADO, T. J. C. Improvement in chemical attributes of Oxisol subsoil and crop yields under no-till. Agronomy Journal, v. 105, n. 5, p. 1393-1403, 2013.

DUGGAL, H; SINGH, P. Comparative study of the performance of M5-Rules algorithm with different algorithms. Journal of Software Engineering and Applications, v. 5, n. 4, p. 270-276, 2012.

GUIMARÃES, A. M.; CATANEO, A.; ZAZUETA, F. Aplicação de computação evolucionária na mineração de dados físico-químicos da água e do solo. Energia na Agricultura, v. 22, n. 1, p. 1-16, 2007.

HOBBS, P. R.; SAYRE, K.; GUPTA, R. The role of conservation agriculture in sustainableagriculture. Philosophical Transactions of the Royal Society B, v. 363, n. 1491, p. 543-555, 2008.

HOLMES, G.; HALL, M.; FRANK, E. Generating rule sets from model trees. In: FOO, N. (Ed.). Advanced Topics in Artificial Intelligence. Proceedings of the 12 th Australian Joint Conference on Artificial Intelligence. Sydney: Springer, 1999. p. 1-12.

MEIRA, C. A. A.; ROGRIGUES, L. H. A.; MORAES, S. A. Análise da epidemia da ferrugem do cafeeiro com árvore de decisão. Tropical Plant Pathology, v. 33, n. 2, p. 114-124, 2008.

PAVAN, M. A. et al. Manual de análise química do solo e controle de qualidade. Londrina: Instituto Agronômico do Paraná, 1992. 38 p. (IAPAR. Circular 76)

PEEL, M. C.; FINLAYSON, B. L.; MCMAHON, T. A. Update world map of the Köppen-Geiger climate classification. Hydrology and Earth System Sciences, v. 11, n. 5, p. 1633-1644, 2007.

RAIJ, B. Van. Gesso na agricultura. Campinas: Instituto Agronômico, 2008. 233 p.

RAIJ, B. Van et al. Recomendações de adubação e calagem para o Estado de São Paulo. Campinas: Instituto Agronômico, 1996. 285 p.

RIBEIRO, A. C.; GUIMARÃES, P. T. G.; ALVAREZ, V. V. $H$. Recomendação para o uso de corretivos e fertilizantes em Minas Gerais: $5^{\text {a }}$ aproximação. Viçosa, MG: Comissão de Fertilidade do Solo do Estado de Minas Gerais, 1999. 359 p.

SORATTO, R.P.; CRUSCIOL, C. Dolomite and phosphogypsum surface application effects on annual crops nutrition and yield. Agronomy Journal, v. 100, n. 2, p. 261-269, 2008.

SOUSA, D. M. G.; LOBATO, E. Correção da acidez do solo. In: SOUSA, D. M. G.; LOBATO, E. (Ed.). Cerrado: correção do solo e adubação. Planaltina, DF: Embrapa Cerrados, 2002. p. 81-96.

TANG, C. et al. Responses of wheat and barley to liming on a sandy soil with subsoil acidity. Field Crops Research, v. 80, n. 3, p. 235-244, 2003.

WITTEN, I. H.; FRANK, E.; HALL, M. A. Data Mining: practical machine learning tools and techniques. 3rd. ed. San Francisco: Morgan Kaufmann, 2011. 629 p.

ZAMBROSI, F. C. B.; ALLEONI, L. R. F.; CAIRES, E. F. Nutrient concentration in soil water extracts and soybean nutrition in response to lime and gypsum applications to an acid Oxisol under no-till system. Nutrient Cycling in Agroecosystems, v. 79, n. 2, p. 169-179, 2007. 